\title{
SECTION 351 TRANSFERS TO CONTROLLED CORPORATIONS: THE FORGOTTEN TERM- "SECURITIES"
}

Tax advisors dealing with a transfer of property to a controlled corporation $^{1}$ often find themselves in a quandary, for although there have been many cases in this area, no clear rule has evolved for deciding whether a given transfer is governed by the nonrecognition provisions of section 351. This situation has come about because courts generally use an analysis that forecloses consideration of an important issue raised by the statute. The Tax Court's recent handling of these cases ${ }^{2}$ illustrates this approach and its defects.

A dispute between the Commissioner and the corporation over the latter's proper basis in the transferred property often raises the question of the applicability of section 351 . If a transfer is governed by section 351 , the basis to the corporation is the same basis that the property had in the hands of the transferor $;^{3}$ whereas if the transfer is not governed by section 351 , the basis to the corporation is its cost. ${ }^{4}$ When the property is depreciable, the Commissioner often disallows part of the corporation's depreciation deduction, contending that the proper basis was that of the transferor and not the cost. Charles E. Curry ${ }^{5}$ demonstrates the advantages that can result from the exclusion of a transfer of depreciable property from section $351 .^{\circ}$

In Curry, four adult members of a family transferred income producing real property to a corporation controlled partly by two of the transferors

I INT. Rev. CoDE of 1954, §351(a):

No gain or loss shall be recognized if property is transferred to a corporation by one or more persons solely in exchange for stock or securities in such corporation and immediately after the exchange such persons are in control ... of the corporation.

INT. Rev. CODE of 1954, § 368(c), defines "control" as:

[T] he ownership of stock possessing at least 80 percent of the total combined voting power of all classes of stock entitled to vote and at least 80 percent of the total number of shares of all other classes of stock of the corporation.

A provision similar to section 351, except for minor variations, has been in every revenue act since 1921 .

2 E.g., Arthur M. Rosenthal, $24 \mathrm{CCH}$ Tax Ct. Mem. 1373 (1965); Charles E. Curry, 43 T.C. 667 (1965), acq., 1965 INT. REv. Bull. No. 38, at 4; Burr Oaks Corp., 43 T.C. 635 (1965).

3 INT. REv. CODE OF 1954, §362(a).

${ }^{4}$ See INT. Rev. Code of $1954, \S 1012$. The cost of the property will ordinarily be the fair market value of what the corporation gives up for it. In the absence of a readily ascertainable market value for what the corporation gives up, the cost will be the fair market value of the transferred property. United States v. Davis, 370 U.S. 65, 72-73 (1962).

543 T.C. 667 (1965), acq., 1965 INT. Rev. Buld. No. 38, at 4.

6 But see INT. REv. CoDE of 1954, §§ 1239, 1245, 1250, which mitigate the benefits gained by transferring depreciable property to a corporation at a stepped up basis. 
and partly by a related third person. ${ }^{7}$ There had been prior negotiations with an outside party. The final terms were basically similar to those offered by the outsider. The transferors received a small cash down payment and took a first and a second mortgage on the property. 8 No restrictions were placed on the right to alienate the corporation's shares, and in fact by the time of trial one of the shareholders had transferred his shares to an unrelated third party.

Judge Forrester, in a decision reviewed by the court, rejected the Commissioner's contention that the transaction was governed by section 351 , holding instead that the transfer constituted a "sale" ${ }^{9}$ and that section 351 does not apply to "sales." 10 The effect of this decision was to allow the corporation to use a $1,400,000$ dollar basis on which to take depreciation rather than the 85,000 dollar basis of the transferors.

Even when the transferred property is not depreciable, the question of the proper basis to the corporation is often disputed. In Burr Oaks Corp. ${ }^{11}$ three individuals who owned a tract of land with a low basis and a high market value transferred it to a new corporation they had organized. The corporation was to subdivide and improve the land and sell it in lots. ${ }^{12}$ The stockholders of the corporation were the wives and brothers of the three transferors and had nothing to do with its operation. In payment for the land each transferor received a two year promissory note bearing six percent interest. During 1959 each received payments from the corporation on the notes. At maturity the notes were extended, and at the time of the trial still had not been paid in full.

Judge Fay, in a decision reviewed by the court, held that the transfer of the land to the corporation was a capital contribution rather than a sale and that the promissory notes given to the transferors in return represented preferred stock..$^{13} \mathrm{He}$ went on to hold the transaction governed by section 351, and that therefore, the corporation took the transferors' basis in the property. ${ }^{14}$ The corporation's taxable income was increased by the

7 The shares before and after the transfer were apportioned as follows:

$\begin{array}{lcc} & \text { Share of Property } & \text { Share of Corporate Stock } \\ \text { Father } & 30 \% & 10 \% \\ \text { Mother } & 30 \% & -\overline{45 \%} \\ \text { Son } & 20 \% & -\overline{45 \%} \\ \text { Daughter } & 20 \% & \overline{100 \%} \\ \text { Son-in-law } & \overline{-} & \end{array}$

8 Principal payments on the second mortgage were not scheduled to begin until the first mortgage was satisfied. In addition principal payments on the second mortgage could be waived if the cash flow from the property was not equal to the sum of cash expenses, payments on the first mortgage, capital expenditures and taxes.

a 43 T.C. at 695.

$10 \mathrm{Id}$. at 697 .

1143 T.C. 635 (1965).

12 This factual situation is a common one. See, e.g., Bruce v. Knox, $180 \mathrm{~F}$. Supp. 907 (D. Minn. 1960) ; Aqualane Shores, Inc., 30 T.C. 519 (1958), aff'd, 269 F.2d 116 (5th Cir. 1959).

1343 T.C. at 649.

$14 I d$. at 651. 
amount its basis in the property was reduced ${ }^{15}$ the transferors were denied capital gains treatment on the sale of the land to the corporation, and their basis for the corporate stock became the same as their basis had been in the exchanged property.16

A related issue often present in these cases is the proper treatment to be given the amounts paid to the transferors on the notes they were given in exchange for the transferred property. The Commissioner often disallows the corporation's interest deduction, contending that the notes represent capital contributions and the payments, dividends. ${ }^{17}$ If the Commissioner prevails, not only is the corporation denied its deduction, but the individual transferors must pay tax on the "dividends" that they had hoped would be treated as tax free principal. This issue, commonly known as the debt-equity issue, arises in many areas of the Code and can hardly be characterized as unique to section 351 cases. ${ }^{18}$ Its determination requires a factual evaluation of all relevant circumstances to see whether the substance of the debt instrument upholds its form. ${ }^{19}$

In handling these cases the courts usually fail to separate the debtequity and nonrecognition issues. The Commissioner usually attempts to have the transfer classified as a capital contribution because the corporation would then be denied both its interest deduction and a stepped up basis. If he is successful, the debt will be "stock" for purposes of section $351 .^{20}$ On the other hand, the corporation's goal is to have the transfer classified as a "sale" 21 because the courts do not apply section 351 to "sales." 22 When a court frames the issue in terms of whether a transfer is a "sale" as opposed to a "capital contribution," it is considering the debtequity issue and the issue of the applicability of section 351 simultaneously, and is thereby foreclosing the possibility of finding the debt valid but the transaction nevertheless within section 351 .

The courts rely on a number of criteria in determining whether a transfer is a "sale." When a transfer is held to be a capital contribution

15 The corporation's basis was reduced from the claimed $\$ 360,000$ to $\$ 100,000$, and when all the lots have been sold its taxable income will have been increased by the $\$ 260,000$ difference.

16 INT. Rev. Code of 1954, §358(a).

17 See, e.g., Castle Heights, Inc. v. United States, 242 F. Supp. 350 (E.D. Tenn. 1965) ; Bruce v. Knox, 180 F. Supp. 907 (D. Minn. 1960); Burr Oaks Corp., 43 T.C. 635 (1965).

18 See Caplin, The Caloric Count of a Thin Incorporation, 17 N.Y.U. INsT. oN FED. TAX 771, 811 n.198 (1959). See generally Goldstein, Corporate Indebtedness to Shareholders: "Thin Capitalization" and Related Problems, 16 TAX. L. REv. 1 (1960). 10 See Gooding Amusement Co., 23 T.C. 408, 418 (1954), aff'd, 236 F.2d 159 (6th Cir. 1956), cert. denied, 352 U.S. 1031 (1957).

20 Burr Oaks Corp., 43 T.C. 635, 649, 651 (1965).

21 See Charles E. Curry, 43 T.C. 667 (1965), acq., 1965 INT. Rev. ButL. No. 38, at 4; Evwalt Dev. Corp., 22 CCH Tax Ct. Mem. 220 (1963); J. I. Morgan, Inc., 30 T.C. 881 (1958), acq., 1959-1 Cum. Bull. 4; Ainslie Perrault, 25 T.C. 439 (1955), acq., 1956-1 CUM. BULI. 5.

22 Arthur M. Rosenthal, 24 CCH Tax Ct. Mem. 1373, 1383 n.4 (1965); Charles E. Curry, supra note 21 ; see Evwalt Dev. Corp., supra note 21 ; J. I. Morgan, Inc., supra note 21 ; Harry F. Shannon, 29 T.C. 702 (1958); Ainslie Perrault, supra note 21 . 
rather than a sale, three factors are most likely to be emphasized. The first is whether the corporation is undercapitalized. Although undercapitalization alone cannot be determinative, ${ }^{23}$ the courts still consider it. ${ }^{24}$

The second factor-variously referred to as "risk of the business" or "anticipated source of payments"-concerns the source of the funds necessary to pay off the corporate debt obligations. Where the transferred property is undeveloped and constitutes the corporation's only significant asset, the payment of the notes is completely dependent upon the successful development of the property. In these cases the courts tend to view the debt obligations as representing a continuing equity interest in the transferred property. ${ }^{25}$ In contrast, when the property already produces sufficient income to cover payments on the notes, the courts are less likely to stress this factor, ${ }^{26}$ although theoretically the payment of the notes is dependent upon the future success of the business.

The third criterion-whether the parties intended to create a bona fide debtor-creditor relationship-is based on a judgment of whether the transferor would enforce the notes if they were not paid, even though enforcement would weaken the corporation's financial position. ${ }^{27}$ In cases where payments were missed and the transferors took no action, ${ }^{28}$ the determination of the intent question is easier than in cases where the notes have always been paid on time. In the latter cases the court must infer the parties' intent.

When the court finds the transferors had a "valid business purpose" for "selling" rather than making a capital contribution, the transfer is likely to be excluded from section 351 regardless of what other factors are

23 See Estate of Miller v. Commissioner, 239 F.2d 729 (9th Cir. 1956). A number of cases have held a transfer to be a sale despite a high debt-equity ratio. E.g., Sun Properties, Inc. v. United States, 220 F.2d 171 (5th Cir. 1955) (ratio of $310: 1$ ); J. I. Morgan, Inc., 30 T.C. 881 (1958), acq., 1959-1 CuM. BuLL. 4 (ratio of 50:1). Compare Caplin, supra note 18, at 777-84, which tells of the complete reliance on the ratio test in the period 1946-1956.

24 E.g., Bruce v. Knox, 180 F. Supp. 907, 912 (D. Minn. 1960); Burr Oaks Corp., 43 T.C. 635,646 (1965) ; Marsan Realty Corp., 22 CCH Tax Ct. Mem. 1513, 1523 (1963).

25 See Aqualane Shores, Inc. v. Commissioner, 269 F.2d 116 (5th Cir. 1959); Castle Heights, Inc. v. United States, 242 F. Supp. 350 (E.D. Tenn. 1965); Bruce v. Knox, supra note 24 ; Burr Oaks Corp., supra note 24 ; Daro Corp., $20 \mathrm{CCH}$ Tax Ct. Mem. 1588 (1961).

26 See Charles E. Curry, 43 T.C. 667 (1965), acq., 1965 Int. Rev. Bull. No. 38, at 4; Aqualane Shores, Inc. v. Commissioner, supra note 25, at 120 (dictum). But see Marsan Realty Corp., 22 CCH Tax Ct. Mem. 1513 (1963). For cases where the court has found a "sale," stressing that the transferred property was not at the risk of the business, see J. I. Morgan, Inc., 30 T.C. 881, 891 (1958), acq., 1959-1 Cum. Bul. 4; Warren H. Brown, 27 T.C. 27,33 (1956), acq., 1957-2 Cun. Bull. 4.

27 Gooding Amusement Co., 23 T.C. 408, 418 (1954), aff'd, 236 F.2d 159 (6th Cir. 1956), cert. denied, 352 U.S. 1031 (1957).

28 See Marsan Realty Corp., 22 CCH Tax Ct. Mem. 1513 (1963) ; cf. R. M. Gunn, 25 T.C. 424 (1955), aff'd per curiant sub nom. Perrault v. Commissioner, 244 F.2d 408 (10th Cir.), cert. denied, 355 U.S. 830 (1957). In Gunn when the Commissioner asserted that the payments on the "notes" were really dividends the corporation stopped making payments in order to avoid further tax if it lost the case. The court noted this stoppage in finding an intent not to enforce payment of the notes. 
present. $^{29}$ For example, the Tax Court found a valid business purpose where the transferor sold equipment to the corporation because a capital contribution in return for stock would have greatly diluted the equity interests of his two business partners and held that section 351 did not apply.30 In other cases where a "sale" is upheld the court is likely to stress the intent of the parties to make a "sale." 31

Although these criteria are relevant to deciding the debt-equity issue, by themselves they are not suited for determining the applicability of section 351 to a given transfer. To begin with, they do not accord with the language of the section. Of course since equity is stock within section 351 , the solution of the debt-equity issue does bear to some extent upon the section 351 problem; but even where the debt is valid, the transfer may come within the section's "securities" provision. Further, the debt-equity criteria do not reflect the underlying policy of section 351. That policy was clearly expressed by Judge Magruder twenty-five years ago:

It is the purpose of [section 351] . . . to save the taxpayer from an immediate recognition of a gain, or to intermit the claim of a loss, in certain transactions where gain or loss may have accrued in a constitutional sense, but where in a popular and economic sense there has been a mere change in the form of ownership and the taxpayer has not really "cashed-in" on the theoretical gain or closed out a losing venture. . . "The transaction described in the statute lacks a distinguishing characteristic of a sale, in that, instead of the transaction having the effect of terminating or extinguishing the beneficial interests of the transferors in the transferred property, after the consummation of the transaction the transferors continue to be beneficially interested in the transferred property and have dominion over it by virtue of their control of the new corporate owner of it." 32

The legislative history ${ }^{33}$ and other cases ${ }^{34}$ accord with this expression of the section's policy.

29 See Estate of Miller v. Commissioner, 239 F.2d 729 (9th Cir. 1956), reversing 24 T.C. 923 (1955) (to continue business after impending death of one of three partners); Warren H. Brown, 27 T.C. 27 (1956), acq., 1957-2 CuM. Bull. 4 (to settle dispute over expansion between two partners).

30 J. I. Morgan, Inc., 30 T.C. 881 (1958), acq., 1959-1 CuM. Bull. 4.

31 See Evwalt Dev. Corp., 22 CCH Tax Ct. Mem. 220 (1963) ; Harry F. Shannon, 29 T.C. 702 (1958).

32 Portland Oil Co. v. Commissioner, 109 F.2d 479, 488 (1st Cir.) (quoting American Compress \& Warehouse Co. v. Bender, 70 F.2d 655, 657 (5th Cir. 1934)), cert. denied, 310 U.S. 650 (1940).

33 See S. Rep. No. 275, 67th Cong., 1st Sess. 11 (1921), in 1939-1 Cum. Burt. 188-89. The 1954 Code made no change in the basic purpose of the section. See H.R. Rep. No. 1337, $83 d$ Cong., 2d Sess. A116 (1954).

34 Cf. Jordan Marsh Co. v. Commissioner, 269 F.2d 453, 456 (2d Cir. 1959) ; Trenton Cotton Oil Co. v. Commissioner, 147 F.2d 33, 36 (6th Cir. 1945) ; Clyde Bacon, Inc., 4 T.C. 1107, 1117 (1945). 
The determination of the "sale" issue does not and can not answer the question of the applicability of section 351 . Its use by the courts, therefore, is improper. Its effect is to foreclose consideration of an important issue raised by the statuory language: Whether the transfer was made "in exchange for stock or securities" of the corporation.

In Campbell v. Carter Foundation Prod. Co ${ }^{35}$ the Fifth Circuit considered the debt-equity and section 351 issues separately. In that case a tax exempt foundation transferred income-producing property to a corporation of which it was the sole stockholder for the purpose of avoiding the tax on unrelated business income. ${ }^{36}$ In return for the property the foundation received a small cash payment and eleven promissory notes which matured over the following five years. Deciding the debt-equity issue first, the court found the corporate notes to represent valid indebtedness and the interest paid thereon to be deductible. ${ }^{37}$ The court then proceeded to consider whether section 351 was applicable, stating the issue as "whether businessmen acting with all honor and sincerity have, or have not, set up a transaction which tax law regards as 'stock' or 'securities." "38 The court then concluded that even though there was a valid business reason for the transfer, no rearrangement of beneficial ownership had taken place, and in the final analysis economic ownership remained the same. ${ }^{39}$ It therefore found the transfer to be within section 351 even though the debt was valid. In addition to separating the two issues, the court avoided the use of the term "sale" and its tendency to divert the court's attention from the proper issue.

If, like Carter, the courts did not use the "sale" analysis, they would have to decide whether valid debt instruments were "securities" for purposes of section 351. Although the term "securities" is not defined in section 351 , it has the same meaning there that it has under the reorganization provisions of the Code. ${ }^{40}$

The scope of that meaning was first outlined in Pinellas Ice \& Cold Storage Co. v. Commissioner ${ }^{41}$ where the Supreme Court held that short term notes were not "securities" on the theory that the notes were equivalent to cash and that the tax free reorganization provision did not apply to cash transactions. ${ }^{42}$ Even though this holding is arguably wrong, ${ }^{43}$ it seems to be well embedded in the tax law. ${ }^{44}$

35322 F.2d 827 (5th Cir. 1963).

36 INT. REV. CODE OF 1954, § 512 .

37322 F.2d at 832 .

38 Id. at 833 .

39 Id. at 835 .

40 Lloyd-Smith v. Commissioner, 116 F.2d 642, 644 (2d Cir. 1941) ; Camp Wolters Enterprises, Inc., 22 T.C. 737, 751 (1954), aff'd, 230 F.2d 555 (5th Cir.), cert. denied, 352 U.S. 826 (1956). For the reorganization provisions, see INT. REv. CoDE OF 1954, $\S \S 354-95$.

41287 U.S. 462 (1933).

42 Id. at 469 (alternative holding).

43 See Griswold, "Securities" and "Contimity of Interest," 58 HARv. L. REv. 705, $706-12,718-25$ (1945). Griswold also states that the decision has led the courts to restrict unduly the scope of the term "securities." Id. at 719.

44 Id. at $722-23$. 
From Pinellas two separate tests developed for deciding whether a given instrument was a "security"-its term and its name. The importance of the term of the instrument follows naturally from the rationale of Pinellas. The rule of thumb was that instruments payable in five years or less did not qualify as "securities" while those for ten years or more qualified. ${ }^{45}$ The Commissioner's position was that notes of less than four years did not qualify as "securities." 48 However, that ruling was withdrawn ${ }^{47}$ in line with his new policy of not issuing advance rulings on whether debt instruments are "stock" or "securities" for purposes of section 351.48

The second factor relied on by the courts was the name given to the debt instrument by the parties. It was thought that "notes" did not qualify as "securities." 49 The dichotomy between notes on the one hand and bonds and debentures on the other had little basis in the case decisions. ${ }^{50}$ The distinction is fortunately no longer used by the courts. ${ }^{51}$ One kind of instrument in which the name may remain important is the "installment sales contract." The Tax Court in Warren H. Brozen ${ }^{52}$ held that a contract calling for ten annual installments with interest on the unpaid balance was not a "security" because "the installment contract in question was not intended to insure the partners a continued participation in the business of the transferee corporation, but was intended rather to effect a termination of such continuing interest." 53 The decision does not seem to be valid. There are no economic differences between a long term installment sales agreement and a formal long term corporate debenture that should lead to different tax consequences under section 351 . The holders of both instruments will have a "continuing interest" in the affairs of the corporation for the duration of the term. The only difference is the amount of the interest and that is not relevant to defining "securities." Furthermore, under the court's theory, no debt that was being amortized could qualify as a "security" regardless of the length of its term. In any event, Brown is the only case holding installment sales contracts not to be "securities."

45 See Camp Wolters Enterprises, Inc., 22 T.C. 737, 751 (1954) ; BrTTKER, FEDmRal INCOME TAXation OF CORPorations aNd Shareholders 82 (1959); Comment, 16 U. Miami L. Rev. 434, 445 (1962).

46 Rev. Rul. 56-303, 1956-2 Cum. BuLr. 193.

47 Rev. Rul. 63-28, 1963-1 Cum. BuLs. 76.

48 Rev. Proc. 62-32, §4.015, 1962-2 Cum. Bull. 527, 532.

49 See Griswold, supra note 43, at 719; Weiss, Notes as Securities Within Section 112(b)(3), 26 TAXES 228 (1948).

50 See id. at 228-30. Compare L \& E Stirn, Inc. v. Commissioner, 107 F.2d 390 (2d Cir. 1939) (bonds held not to be securities), zerith Burnham v. Commissioner, 86 F.2d 776 (7th Cir.), cert. denied, 300 U.S. 683 (1936) (notes held to be securities).

${ }^{51}$ See Camp Wolters Enterprises, Inc., 22 T.C. 737, 750-51 (1954). Bittker questions the need for any formal instrument in a close corporation, contending that the corporation's promise on open account has the same meaning to the shareholder as a bond or note. BITTKER, op. cit. supra note 45 , at 104.

5227 T.C. 27 (1956), acq., 1957-2 Cum. Butz. 4.

$53 I d$. at 36. 
The current test used by the courts was announced by the Tax Court in Camp Wolters Enterprises, Inc.54 where five to nine year subordinated notes were held to be "securities" within section 351:

The test . . . is not a mechanical determination of the time period of the note. Though time is an important factor, the controlling consideration is an over-all evaluation of the nature of the debt, degree of participation and continuing interest in the business, the extent of proprietary interest compared with the similarity of the note to a cash payment, the purposes of the advances, etc. .5

Since the courts so rarely reach the "securities" issue, and since the only case since Camp Wolters to consider it thoroughly was the incorrectly decided Brown case, it is not clear how the test will operate as compared to the term test. It is probable that the new test will treat short term debt of the Pinellas type and long term debt in the same manner as before. The holding in Camp Wolters suggests that debt falling within these two extremes will more likely be classified as "securities" under the new test than they were under the old term test.

This general test will probably be used to decide most of the cases that arise. However, other factors may be employed in solving specific problems as, for example, where an individual ${ }^{56}$ transfers property to a corporation of which he is the sole shareholder in exchange for debt instruments of the corporation. On these facts the court in the Carter case ${ }^{57}$ held the transfer to be within section 351 without specifying whether the notes were "stock" or "securities." 58 Although the court's finding that the debt was valid ${ }^{59}$ seems to indicate that the notes were "securities," its express refusal to categorize them at all may mean that it was not concerned about an exact classification. This would not be inexplicable, since the policy of section 351 applies to all cases where, because the transferor is the sole shareholder of the corporation, it is impossible to have a shift in beneficial ownership.

The beneficial ownership test, however, works only in cases like Carter where it is literally impossible to have a change in beneficial ownership. ${ }^{60}$ Otherwise, the reasoning behind its application would become circular, since the extent of beneficial ownership is measured by ownership of "stock" or "securities": section 351 is inapplicable only if there is a genuine re-

5422 T.C. 737 (1954).

$55 \mathrm{Id}$. at 751.

56 The transferor-shareholder could also be a group. See Arthur M. Rosenthal, $24 \mathrm{CCH}$ Tax Ct. Mem. 1373 (1965).

67 Campbell v. Carter Foundation Prod. Co., 322 F.2d 827 (5th Cir. 1963).

$58 I d$. at $833-35$.

59 Id. at 831 .

${ }^{60}$ Curry would have been such a case except that the court found as a fact that the parties, despite their family relationship, had dealt with each other at "arms length." Charles E. Curry, 43 T.C. 667, 687 (1965), acq., 1965 INT. REv. BuLL. No. 38 , at 4. 
arrangement of beneficial interest, but there is a genuine rearrangement of beneficial ownership only if the notes are not "securities." Thus in Curry, when the Tax Court held section 351 inapplicable because of the disproportion between stock and note ownership, ${ }^{61}$ it held by implication that the notes were not "securities." The issue the court said it did not have to decide ${ }^{62}$ was therefore the key to the correctness of its decision.

There were two promissory notes issued by the transferee corporation to the transferors in Curry. The first was for ten years, secured by a first mortgage and provided for equal semi-annual principal payments plus interest on the unpaid balance. ${ }^{63}$ The second note, secured by a second mortgage, required semi-annual interest payments on the unpaid balance with principal payments to start in the eleventh year and to continue for ten years in equal annual installments. ${ }^{64}$ There was also a waiver clause on second mortgage principal payments under certain circumstances. ${ }^{65}$

Considering the twenty year length of the second note, the absence of principal payments for ten years, and the waiver clause, the note should be classified as a "security." 66 The first mortgage note is harder to classify. On its face it is very similar to the installment sales contract which Brown held not to be a "security." But even assuming that Brown is right, ${ }^{67}$ Curry is distinguishable because the continued subordination of payments to other expenditures ${ }^{68}$ tends to show that the instrument evidenced a "continuing interest" in the corporation's business.

Curry illustrates the danger the "sale" analysis presents to the proper handling of section 351 cases. In that case the "sale" approach led to the wrong result. These problems could be avoided if the courts would consider the cases in light of the issues raised by the statutory language of section 351 rather than by looking for a "sale."

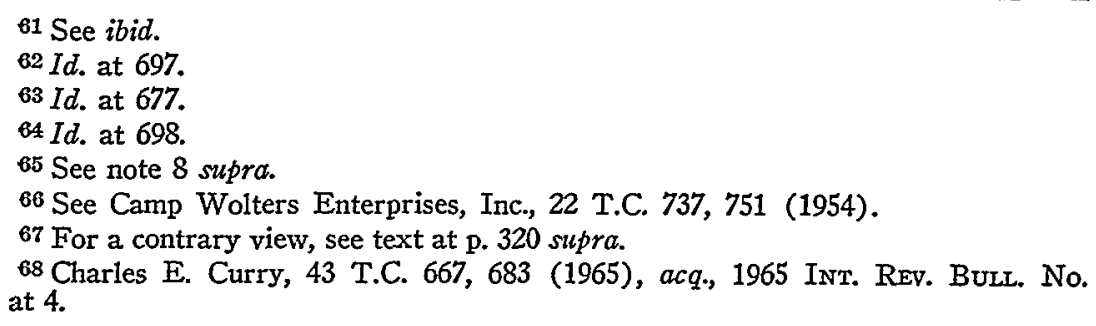

